\title{
Three Uncommon Seaweeds of the Pacific Coast of Mexico
}

\author{
A. Catalina Mendoza-González, Luz Elena Mateo-Cid, Deisy Yazmín García-López \\ Departamento de Botánica, Escuela Nacional de Ciencias Biológicas, Instituto Politécnico Nacional, Campus \\ Santo Tomás, México City, México \\ Email: am7124@gmail.com
}

Received 19 October 2015; accepted 11 December 2015; published 14 December 2015

Copyright (C) 2015 by authors and Scientific Research Publishing Inc.

This work is licensed under the Creative Commons Attribution International License (CC BY). http://creativecommons.org/licenses/by/4.0/

(c) (i) Open Access

\begin{abstract}
This report describes a new record and two unusual and rare species of marine algae collected from Oaxaca, Michoacán, Jalisco and Baja California Sur at Mexican Pacific coast. Boodleopsis verticillata is the first record in the Pacific shore of Mexico, in the case of Melobesia polystromatica, this is the sixth record at tropical Pacific while Litholepis sonorensisis reported for the third time in the Gulf of California. These results suggest that the taxonomic inventory of seaweed in the Pacific coast of Mexico is not yet complete, so attention must be given to the epiphytes, and other small and delicate species that inhabit the coast of Mexico. Morphological descriptions, distributional range, reproductive stage and samples examined are included.
\end{abstract}

\section{Keywords}

Bryopsidales, Corallinales, Distribution, New Records, Seaweeds

\section{Introduction}

The Pacific coast of Mexico is considered one of the most diverse regions in species richness of seaweeds, to date there have been reported 1120 species of marine algae; in particular the western coast of the Peninsula de Baja California shows the greater number of species (742 taxa) [1]. The number of species, new records and descriptions of new species of marine algae in the Mexican Pacific has been increased in recent years [2]-[7]. Despite this fact the marine floral inventory is still incomplete and more complete surveys are still needed, especially on epiphytes that are small habit and go unnoticed by their size. In this study, we provide the first record of Boodleopsis verticillata E.Y. Dawson from the Mexican Pacific coast. The other species are Melobesia polystromatica E.Y. Dawson and Litholepis sonorensis E.Y. Dawson, which includes the extension in its distribution interval in Oaxaca, Michoacan and Baja California Sur. Information on the morphology, reproductive stage, localities and habitats of the three species, are provided.

How to cite this paper: Mendoza-González, A.C., Mateo-Cid, L.E. and García-López, D.Y. (2015) Three Uncommon Seaweeds of the Pacific Coast of Mexico. American Journal of Plant Sciences, 6, 3187-3192.

http://dx.doi.org/10.4236/ajps.2015.619310 


\title{
2. Material and Methods
}

Collections were carried from the intertidal zone in Calerita in Baja California Sur, this place is a shallow sandy beach with rocky aggregates and tidepools; Tenacatita Bay is situated in the state of Jalisco, is a large sandy beach with coral reef and formation of extensive intertidal pools. As regards to Michoacan, specimens were collected in Faro; this place is characterized by a sandy beach with rocky areas exposed high waves. Finally, San Agustinillo is situated in Oaxaca, this locality has three small bays, one of which is a sandy beach that is protected by rocks, and during low tides intertidal pools are formed. Specimens were collected by hand and free diving between 1 - 4 m depth using spatulas and knives; any particular sampling method was not used, but the study area was systematically reviewed. The samples were fixed in formalin solution at 5\% in seawater, placed in plastic bags and transported to the Department of Botany of the National School of Biological Sciences of the National Polytechnic Institute. Preserved specimens of Boodleopsis verticillata were stained with green iodine for anatomical examination using optical microscope. In the case of Melobesia polystromatica and Litholepis sonorensis small fragments were decalcified with $0.6 \mathrm{M} \mathrm{HNO}_{3}$ and dehydrated with ethyl alcohol at different concentrations (10\%, 20\%, 30\%, 40\%, 50\%, 60\%, 70\%, 80\%, 90\% and absolute ethyl alcohol). These fragments were embedded into paraffin blocks and subsequently sections of the specimens were made with a manual rotation Microtome American Optical ${ }^{\circledR}$, these sections were fixed on slides with Ruyter's adhesive [8], and stained with hematoxilin-eosine [5]. After this process the slides were observed using an Olympus microscope (CX31, Philippines) and observations of vegetative and reproductive structures were performed in order to determination both species. For determination and descriptive terminology we followed specialized literature [9]-[11]. Photomicrography was conducted with a digital camera (CANON D20, Japan). The figures were edited using Adobe $^{\circledR}$ Photoshop ${ }^{\circledR} 7.0$ (Adobe Systems Inc., San Jose, USA). Specimens are housed at herbarium (ENCB) of the National School of Biological Sciences of the Instituto Politécnico Nacional Herbarium abbreviations follow the online Index Herbariorum (http://sciweb.nybg.org/science2/IndexHerbariorum.asp). Appropriate comments about the morphology, specimens examined and distribution are provided for each species.

\section{Results}

Three unusual and rare species were found during the present study.

\author{
Phylum Chlorophyta \\ Class Ulvophyceae \\ Order Bryopsidales \\ Family Udoteaceae \\ Boodleopsis verticillata E.Y. Dawson 1960a: 32 [12].
}

Type locality: Bahia San Telmo. Isla del Rey, Islas Perlas, Pacific Panamá.

Specimens Examined Morpho-anatomically (Figures 1(a)-(d)). MÉXICO: Oaxaca: San Agustinillo (96³1'49"W, 15³9'54"N), Mateo-Cid, Mendoza-González \& García-López, 28-06-2013, (ENCB 13-70/04).

Habitat and Morphology: On rocks, intertidal, thallus forming a loose turf of closely congested branched coenocytic filaments.

Anatomy: Thallus small, generally forming cushions or turfs of creeping, branching mostly dichotomous, rarely trichotomous or verticillate, interwoven siphons and creeping or semi-erect branches anchored by scattered rhizoids. Basal coenocytic filaments 120 - $150 \mu \mathrm{m}$ diameter and 360 - $720 \mu \mathrm{m}$ long between dichotomies. The apices of the filaments measured 50 - $70 \mu$ m diameter.

Reproductive structures: Gametangia borne sparingly on primary rhizoidal filaments, ovoid to $120 \mu \mathrm{m}$ diameter and $150 \mu \mathrm{m}$ long, with a long pedicel, without septum.

Comments: The vegetative structure of these plants is clearly similar that described by Dawson [12]. The Mexican plants are in general agreement with the dimensions reported for Panamanian plants. The two previous Pacific coast records of Boodleopsis verticillata is from Panama and Salvador. This is the first record of this species in the Pacific coast of Mexico.

Distribution: Florida, USA, Costa Rica, El Salvador, Panamá, Caribbean, Philippines [9] [13].

Phylum Rhodophyta

Class Florideophyceae

Order Hapalidiales

Family Hapalidiaceae 


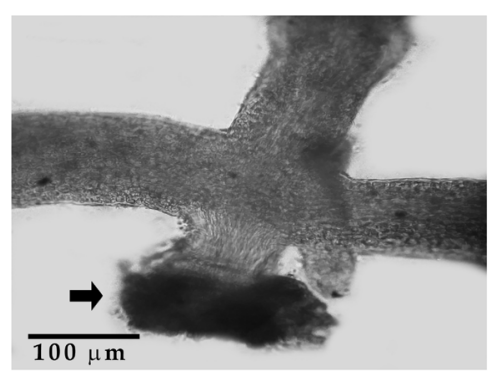

(a)

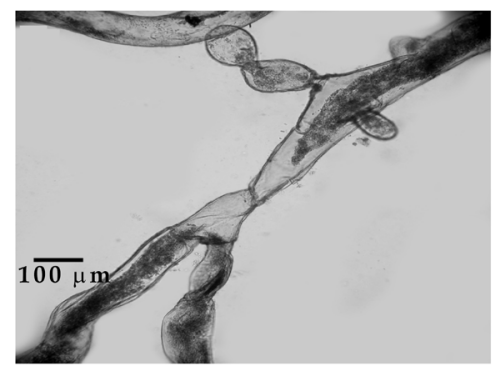

(c)

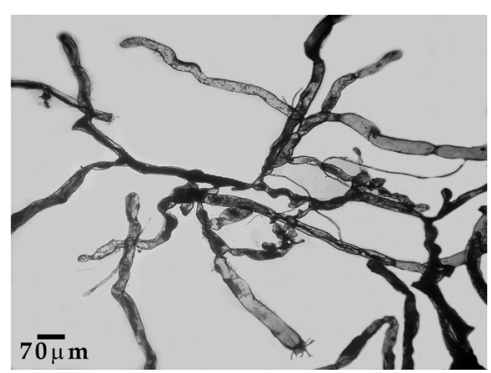

(b)

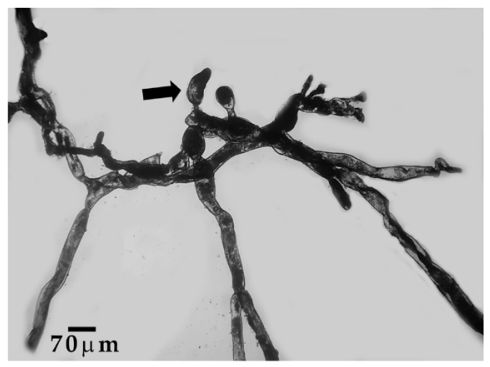

(d)

Figure 1. Boodleopsis verticillata. (a) Branches anchored by rhizoids (arrow); (b) Habit of thalli irregularly branched; (c) Siphons dichotomously branched; (d) Ovoid gametangia (arrow) borne sparingly on primary rhizoidal filaments. The specimens were stained with green iodine.

Melobesia polystromatica E.Y. Dawson 1960b: 8-9 [14]

Type locality: Bahia Tenacatita, Jalisco, Mexico.

Specimens Examined Morpho-anatomically (Figures 2(a)-(f)). MÉXICO: Jalisco: Bahia Tenacatita (10449'00"W, 19¹3'15"N), ๑, Mendoza-González, Mateo-Cid \& Huerta-Múzquiz; 05-10-1991 (ENCB 20681);

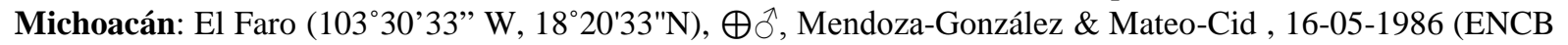
20682); Oaxaca: Santa Elena ( $\left.96^{\circ} 44^{\prime} 38^{\prime \prime} \mathrm{W}, 15^{\circ} 43^{\prime} 14 " \mathrm{~N}\right), \oplus{ }^{\wedge}$ \% , Mendoza-González \& Mateo-Cid, 08-05-1997 (ENCB 13562); San Agustín Bay, El Coyote (96¹4'09"W, 1541'21"N), $\oplus \widehat{\jmath}$, Mendoza-González, Mateo-Cid \&Galicia-García, 06-12-1994 (ENCB 20683).

Habitat and Morphology: On Sargassum liebmannii, intertidal. Thalli encrusting, following the contour of host stipe, without protuberances, attached to the substratum ventrally by cell adhesion, 100 to $200 \mu \mathrm{m}$ thick.

Anatomy: Thallus construction dimerous throughout composed of two groups of filaments: a ventral-most unistratose layer of filaments from which marginal growth occurs; and upright filaments; 15 - 20 cells long arise perpendicularly from cells of ventral filaments and lead to increased thallus thickness. In transverse section the cortical cells oblong or rectangular 4 - $5 \mu \mathrm{m}$ wide and 5 - $6 \mu \mathrm{m}$ long; epithallus unistratose with rounded cells 18 - $20 \mu \mathrm{m}$ wide and $14-16 \mu \mathrm{m}$ long. In the medulla and cortex are numerous cell fusions, secondary pit-connections not seen.

Reproductive structures: Tetrasporangial conceptacles scattered over the thallus, roofs of tetrasporangial conceptacles multiporate, tetrasporangia each containing four zonately arranged spores and producing an apical plug. Chambers measure 130 - $140 \mu \mathrm{m}$ diameter and 50 - $55 \mu \mathrm{m}$ high, tetrasporangia 18 - $20 \mu \mathrm{m}$ diameter and 40 - $45 \mu \mathrm{m}$ long, arranged across the floor of the conceptacle, and a central columella is absent.

Gametangial thalli are dioecious, spermatangial plants $100-150 \mu \mathrm{m}$ thick with the same vegetative structure as tetrasporangial plants. Uniporate conceptacles protruding, not apiculate, scattered, conceptacle chambers usually $70-80 \mu \mathrm{m}$ in diameter and $55-60 \mu \mathrm{m}$ high containing branched spermatangial branches on the chamber floor, the walls and the roof. Carposporangial conceptacles uniporate, protruding, rounded and more frequent than males, the chambers without columella, chambers 115 - $120 \mu \mathrm{m}$ diameter and 80 - $85 \mu \mathrm{m}$ high, canal 15 $20 \mu \mathrm{m}$ long. Carposporangia develop on the floor of the chamber and measure $20-25 \mu \mathrm{m}$ in wide and $40-50$ $\mu \mathrm{m}$ long.

Comments: This species was described by Dawson [14] based on specimens collected in Bahia Tenacatita, Jalisco México. The thallus was described as $0.5-0.8 \mathrm{~cm}$ thick; when encircling cylindrical parts of host, 100 - 


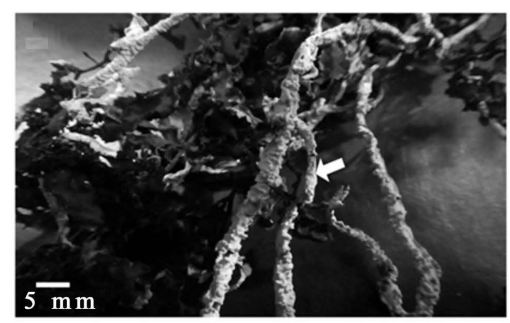

(a)

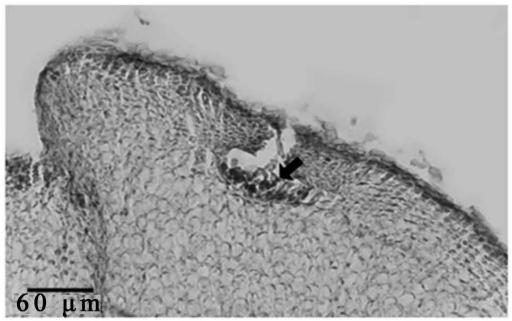

(c)

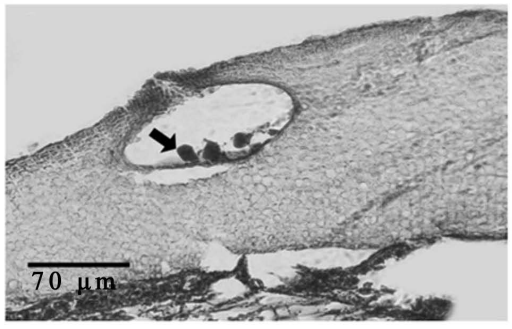

(e)

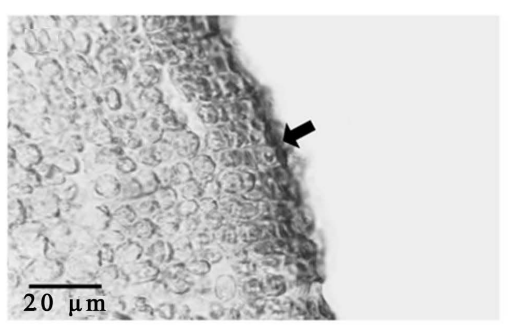

(b)

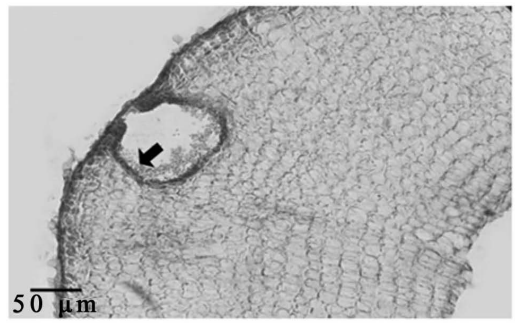

(d)

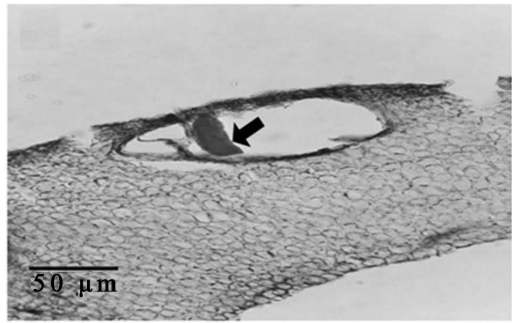

(f)

Figure 2. Melobesia polystromatica. (a) Habit of crustose thalli (arrow) attached to brown algae; (b) Section through dorsal region noted epithallial cells (arrow); (c) Section through female conceptacle with carpogonial branches (arrow); (d) Mature male conceptacle with spermatangial branched filaments on floor and walls of chamber (arrow); (e) Section through mature carposporangial conceptacle showing a terminal carposporangium (arrow); (f) Section through mature tetrasporangial multiporate conceptacle showing tetrasporangium (arrow). The specimens were stained with hematoxilin-eosine.

$200 \mu \mathrm{m}$ thick. He also mentioned that mature parts of thalli has an extensive cortical region and an epithallium of 4 - 5 layers of small, quadrate to flattened cells. In general, the features observed in our specimens are similar to those described by Dawson [14]. On the other hand, $M$. polystromatica had considerable similarities with some of the thin species of Lithothamnion, consequently this species needs further morphological and molecular study of its taxonomic status [15] [16].

Distribution: Gulf of California, Nayarit, Jalisco, Michoacán, Oaxaca, México; El Salvador [15].

\section{Phylum Rhodophyta}

Class Florideophyceae

Order Corallinales

Family Corallinaceae

Litholepis sonorensis E.Y. Dawson 1960b: 59 [14].

Type locality: Isla Espíritu Santo near La Paz, Baja California Sur, Mexico.

Specimens Examined Morpho-anatomically (Figures 3(a)-(d)). MÉXICO: Baja California Sur. Calerita (110¹6'38"W, 2420'56"N), ๑, Mendoza-González \& Mateo-Cid, 24-04-1994 (ENCB 20680).

Habitat and Morphology: On Lithophyllum sp. Intertidal pools

Anatomy: Crusts thin, delicate, gray-white, spreading; 1 cell layer in vegetative portions; thicker at conceptacle, 2 - 5 cell layers when thalli overgrow each other; cell layer of rectangular cells, variable in height, 20 - 25 (30) $\mu \mathrm{m}$ tall and 13 - $15 \mu \mathrm{m}$ wide. 


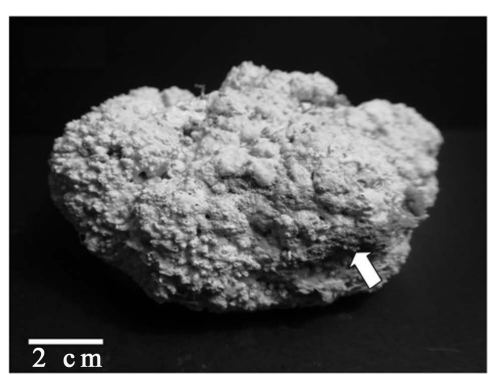

(a)

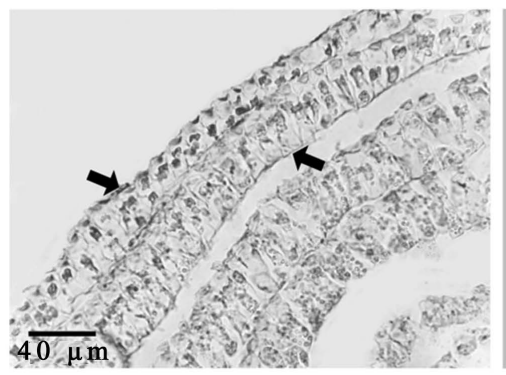

(c)

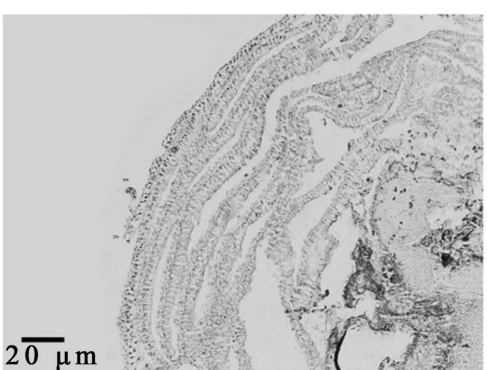

(b)

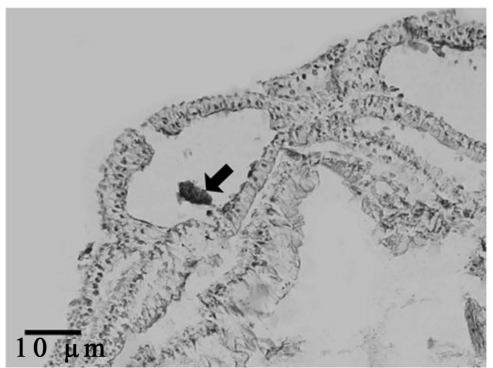

(d)

Figure 3. Litholepis sonorensis. (a) Habit of a plant encrusting pebbles (arrow); (b) Thallus section showing extensively superimposed crusts; (c) Habit of a plants on Lithophyllum sp. (arrow); (d) Section through mature tetrasporangial conceptacle showing tetrasporangium (arrow). The specimens were stained with hematoxilin-eosine.

Reproductive structures: Sporangial conceptacles conical, chambers measure 250 - $350 \mu \mathrm{m}$ diameter and 75 $100 \mu \mathrm{m}$ high; only slightly protruding, up to $50 \mu \mathrm{m}$ above crust surface; with a single pore; with flat floor of single cell layer and roof of 2 - 3 cell layers; tetrasporangia 50 - $60 \mu \mathrm{m}$ long, 25 - $30 \mu \mathrm{m}$ wide.

Female and male conceptacles not observed.

Comments: Litholepis sonorensis is only known from the type and Zihuatanejo, Guerrero, this is the third report in the Gulf of California. This species requires being re-evaluated in order to confirm its taxonomic status.

Distribution: Baja California Sur, Guerrero [16].

\section{Discussion}

The absence of records of Boodleopsis verticillata, Melobesia polystromatica and Litholepis sonorensis along the Tropical Pacific coast of Mexico may be due to lack of attention on epiphytic species, misapplied names and the small size of the thallus, many of these species can be confused with other genera of algae so it is necessary that the specimens are in reproduction, which facilitates species determination. In the case of $B$. verticillata it is important to emphasize the significance of reproductive structures, since the presence of these facilitates the identification of the species. Concerning to M. polystromatica and L. sonorensis these were encountered growing as epiphytes; this suggests that it is very important to conduct studies on epiphytic algae because epiphytism is an important variable in the study of the structure of benthic marine algae communities.

\section{Conclusion}

The results obtained in this study allowed us to view the importance of floristic study of seaweeds in regions of Mexico's Pacific Tropical coast poorly known, as well as the importance of knowing the diversity of epiphytic algae which are not well known in the regional flora.

\section{Acknowledgements}

The first and second authors thank for the fellowship granted under the program of exclusivity (Beca de Exclusividad) of the "Comisión de Operación y Fomento de Actividades Académicas-IPN (COFAA)", the program 
“Estimulo al Desempeño de Investigadores-IPN (EDI)” and Instituto Politécnico Nacional for the financial support (SIP-20150767 and 20150850).

\section{References}

[1] Aguilar-Rosas, R., Aguilar-Rosas, L.E., Mateo-Cid, L.E. and Mendoza-González, A.C. (2007) New Records of Marine Rhodophyta from the Pacific Coast of Mexico. Algae, 22, 153-157. http://dx.doi.org/10.4490/ALGAE.2007.22.3.153

[2] Pedroche, F.F. and Sentíes, A. (2003) Ficología Marina Mexicana. Diversidad y Problemática Actual. Hidrobiológica, 13, 23-32.

[3] Broom, J.E., Nelson, W.A., Yarish, C., Jones, W.A., Aguilar-Rosas, R. and Aguilar-Rosas, L.E. (2002) A Reassessment of the Taxonomic Status of Porphyra suborbiculata, Porphyra carolinensis and Porphyra lilliputiana (Bangiales, Rhodophyta) Based on Molecular and Morphological Data. European Journal of Phycology, 37, 227-235. http://dx.doi.org/10.1017/S0967026202003566

[4] Aguilar-Rosas, R., Aguilar-Rosas, L.E., Avila-Serrano, G. and Marcos-Ramírez, R. (2004) First Record of Undaria pinnatifida (Harvey) Suringar (Laminariales, Phaeophyta) on the Pacific Coast of Mexico. Botanica Marina, 47, 255258. http://dx.doi.org/10.1515/BOT.2004.028

[5] Aguilar-Rosas, R., Aguilar-Rosas, L.E. and Pedroche, F.F. (2005) Ulva fasciata Delile (Ulvaceae, Chlorophycota): A Species Newly Introduced into Pacific Mexico. Botanica Marina, 48, 46-51. http://dx.doi.org/10.1515/bot.2005.005

[6] Mateo-Cid, L.E., Mendoza-González, A.C., Gavio, B. and Fredericq, S. (2005) Grateloupiahuertana sp. nov. (Halymeniaceae, Rhodophyta): A Peculiar New Prostrate Species from Tropical Pacific Mexico. Phycologia, 44, 4-16.

[7] Mendoza-González, A.C., Sentíes, A., Mateo-Cid, L.E., Díaz-Larrea, J., Pedroche, F.F. and Alvarado-Villanueva, R. (2011) Ochtodes searlesii sp. nov. (Gigartinales, Rhodophyta), from the Pacific Tropical Coast of Mexico, Based on Morphological and Molecular Evidence. Phycological Research, 59, 250-258. http://dx.doi.org/10.1111/j.1440-1835.2011.00623.x

[8] Martoja, R. and Martoja-Pierson, M. (1970) Técnicas de Histología Animal. Toray-Masson, Barcelona.

[9] Littler, D.S. and Littler, M.M. (2000) Caribbean Reef Plants: An Identification Guide to the Reef Plants of Caribbean, Bahamas, Florida and Gulf of Mexico. Offshore Graphics, Washington DC.

[10] Peña, V., Adey, W.H., Riosmena-Rodríguez, R., Jung, M.Y., Afonso-Carillo, J., Choi, H.G. and Bárbara, I. (2011) Mesophyllum sphaericum sp. nov. (Corallinales, Rhodophyta): A New Maërl-Forming Species from the Northeast Atlantic. Journal of Phycology, 47, 911-927. http://dx.doi.org/10.1111/j.1529-8817.2011.01015.x

[11] Mateo-Cid, L.E., Mendoza-González, A.C. and Gabrielson, P.W. (2014) Neogoniolithon (Corallinales, Rhodophyta) on the Atlantic Coast of Mexico, including N. siankanensis sp. nov. Phytotaxa, 190, 64-93. http://dx.doi.org/10.11646/phytotaxa.190.1.7

[12] Dawson, E.Y. (1960a) New Records of Marine Algae from Pacific Mexico and Central America. Pacific Naturalist, 1, 31-52.

[13] Guiry, M.D. and Guiry, G.M. (2015) Algae Base Version 4.2. World-Wide Electronic Publication, National University of Ireland, Galway. http://www.algaebase.org

[14] Dawson, E.Y. (1960b) Marine Red Algae of Pacific Mexico. Part 3. Cryptonemiales, Corallinaceae subf. Melobesioideae. Pacific Naturalist, 2, 3-125.

[15] Fernández-García, C., Riosmena-Rodríguez, R., Wysor, B, Tejada, O.L. and Cortéz, J. (2011) Checklist of the Pacific Marine Macroalgae of Central America. Botanica Marina, 54, 53-73. http://dx.doi.org/10.1515/bot.2011.001

[16] Norris, J.N. (2014) Marine Algae of the Northern Gulf of California II: Rhodophyta. Smithsonian Contributions to Botany, 96, 1-555. http://dx.doi.org/10.5479/si.19382812.96 